\title{
A Study on Gender Differences in Food Habits and Sport Performance among Secondary School Boys and Girls in Sri Lanka 斯里蘭卡中學生的敛食行為與運動表現
}

\author{
Walter SENEVIRATHNE \\ Department of Education, Faculty of Arts, \\ University of Peradeniya, SRI LANKA
}

韋特.施尼偉堤

斯里蘭卡佩拉德尼亞大學

文學院教育學系

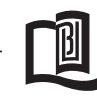

\begin{abstract}
The objectives of this research were to identify the significant difference between students food habits at different periods of sport activity, to identify gender differences in food habits and to identify sport performance in food habits and, sport performance among secondary school boys and girls. A descriptive survey method was adopted. The situation sampling method (non-randomized) was used to select 10 secondary schools and 100 students $(\mathrm{N}=100)$ including 50 girls and 50 boys who are aged between 17-19. Data were obtained by distribution questionnaires to the sample and the data were analyzed using a bi-nominal probability test and Pearson's chi-square test and descriptive method. The mixed results were revealed in this research (both significant difference and no significant difference) in food habits and sport performance. The bi-nominal probability test implies that in the pre exercise period, those who got good food habits shows high level of performance among girls than boys. However for the water intake no significant difference was recorded During the exercise period those who got good food habits instead of showing high level of performance among girls than boys. However no significant difference in other drinks habits. Regarding post exercise period significant difference was recorded with interruptions for food habits and protein intake. Pearson's chi squire test, shows DF (12) P value $=0.839$ twelve cells with expected counts less than 5.0. According to the chi test, no significant difference of sport performance with two habits were found in terms of gender and nature of game (indoor and outdoor). This study also reveals that the food habits of both boys and girls were quite traditional.
\end{abstract}

\section{摘 要}

本文旨在探討斯里蘭卡中學生的飲食行為與運動表現, 採用問卷形式共調查了一百位男女中學生, 結果顯示他們的飲食行為 與運動表現都較為傳統的。

\section{Introduction}

Sports is a science that requires a solid understanding of the nutritional factors effecting performance, recovery and health, a knowledge of the nutritional value of food and fluids, and necessary skills to implement appropriate nutritional strategies into daily training and competition.

Knowledge and its application of the nutritional habits help boys and girls to uplift their performances. As A.I.S department (Australian Institute Sports) there can be divide 
three main periods (phases) in the sport activity such are pre event preparation period, during the exercise and post recovery period.

Sri Lankan Sport Bodies are searching for new strategies to improve performances of men and women in sports competitions. It can also found that there is a considerable progress in sport performances in secondary schools in recent years.

This research focuses on the food habits and sports performance of teenagers in secondary schools of Sri Lanka. The main objectives of the research were to identify the salient differences in food habits of students at different periods of a sport activity and to identify gender differences in food habits and sport performance among secondary school boys and girls.

\section{Methods}

Descriptive survey method was adopted to identify the significant differences between students' food habits at pre- exercise, during exercise and post exercise periods and to identify the gender differences in food habits and sport performance.

\section{Samples}

Situation sampling methods (non-randomized) was used to select 10 secondary schools in the Kandy District from the 10 schools selected 100 students $(n=100)$ including 50 girls and 50 boys among aged between 1719 sportsman and woman.

Table 1. The Research Sample.

\begin{tabular}{lll}
\hline School & Girls & Boys \\
\hline St. Sylvester's College & & 10 \\
Dharmaraja College & & 10 \\
Girls High School College & 10 & \\
Pushpadana Girls College & 10 & \\
Kingswood College & 10 & 10 \\
St. Anthony's College & & 10 \\
Vidyartha College & & 10 \\
A Rathnayake College & 10 & \\
St. Anthony's Girls College & 10 & \\
\hline
\end{tabular}

\section{Data Collection and Analysis}

Data were obtained from questionnaire (the questionnaire were prepared according the AIS Department of Sports Nutrition) and distributing \& getting students responses. Descriptive method and two major statistical methods, viz: Bi-nominal probability test and Pearson's Chi-square test, were used to analyze data. These tests were used to analyze the significance of students' food habits at three different periods of sport activity. The analysis was used to identify the gender differences in food habits, and to assess the sport performances among secondary school boys and girls. Bi-nominal probability test was used and the following hypotheses were formed:
P1 = Probability of performance of girls under good and weak food habits

P2= Probability of performance in boys under good and weak food habits.

The hypotheses were:

$\mathrm{H}_{0}: \quad \mathrm{P}_{1}-\mathrm{P}_{2}=0 \quad$ Probability of the performance of girls under good and weak food habits are not greater than boys

$\mathrm{H}_{1}: \mathrm{P}_{1}-\mathrm{P}_{2}>0$ Probability of the performance of girls under good and weak food habits are greater than boys

$\mathrm{P}_{1}-\mathrm{P}_{2} \quad$ were statistically tested by one tail binomial probability test. The test scores were recognized as $\mathrm{P}$ value. These $\mathrm{P}$ values were calculated on various food habits for the pre-exercise, exercise and post-exercise periods. 


\section{Results}

To analyze data in this research were used two major statistical methods. Bi-nominal probability test and Pearson's Chi-square test was used to analyze the significant between students food habits at three different periods of sport activity and to identify the gender differences in food habits and sport performance among secondary school boys and girls in Sri Lanka. Table 2 shows the levels pre-exercise, during exercise and post exercise period, food habit and sport performance.

Table 2. Levels Pre-exercise, during Exercise and Post-exercise Period, Food Habit and Sport Performance.

\begin{tabular}{llll}
\hline Phase of the sport activity & Treatment & $\begin{array}{l}\text { P value of the } \\
\text { performances }\end{array}$ & Significant or not \\
\hline Pre-Exercise period & Breakfast & 0.0064 & Significant \\
& Lunch & 0.006 & Significant \\
& Dinner & 0.003 & Significant \\
Carbohydrate & 0.0197 & Significant \\
& Protein & 0.0192 & Significant \\
& Water & 0.22 & No Significant \\
& Snack & 0.021 & Significant \\
& Drinks & 0.0162 & Significant \\
Supplementary diet & 0.0005 & Significant \\
Carbohydrate & 0.0005 & Significant \\
Wuring exercise period & 0.0192 & Significant \\
& Drinks & 0.32 & No Significant \\
& Protein & 0.0268 & Significant \\
Carbohydrate & 0.22 & No Significant \\
& Water & 0.026 & No Significant \\
& Interruption & 0.0005 & Significant \\
\hline
\end{tabular}

According to the Bi-nominal test the girls who had good food habits in the Pre-exercise period showed a higher level of performance than the boys of similar category (For breakfast, lunch and dinner; carbohydrate, protein, snack, and drinks intake; and for supplementary diets $\mathrm{P}$ values are less than 0.05). Regarding the water intake (where $\mathrm{P}>0.05$ ) no significant difference was recorded. In the period during exercise, girls who followed good food habits showed higher level of performance than boys in carbohydrate and water intake habits (where $\mathrm{P}<0.05)$. However, no significant difference in performance in other drink habits (where $\mathrm{P}>0.05$ ) was observed. After the exercise, significant difference in performance was shown by girls than boys with a protein intake and post exercise interruption. Regarding the carbohydrate and water intake no significant difference was recorded.
Research revealed that in the pre exercise period $95 \%, 70 \%$ and $100 \%$ of the participant report eating breakfast, lunch and dinner daily. Breakfast skipping is not statistical linked to the gender. Water intake, consumed beverages, consumption frequencies have been described more in details elsewhere such as the results of the dietary survey (Caradini et al, 1999 Narring et al 1997). But there was significant difference in lunch habits among boys and girls (62\% vs $89 \%$ respectively $\mathrm{P}<0.001)$.

Research found no difference in meal and snack frequency of consumption between girls and boys. As expected the directory survey shows that mean daily energy intake is lower among girls than among boys. Both boys and girls food habits are quite traditional. 
During the exercise period significant different boys and girls in carbohydrate intake (48\% vs $27 \%$ respectively $\mathrm{P}<0.001$ ) and total $37 \%$ was a very low. (comparing to the standard $7-10 \mathrm{~g}$ per $\mathrm{kg}$ body mass).
Probability of sport performance under good and weak food habits were estimated with the gender under the three stages of the sport activities. Diagram 01 and 02 shows the patterns of the sport performance.

Figure 1. Probability of the Sports Performance of Girls and Boys under Week Food Habits.

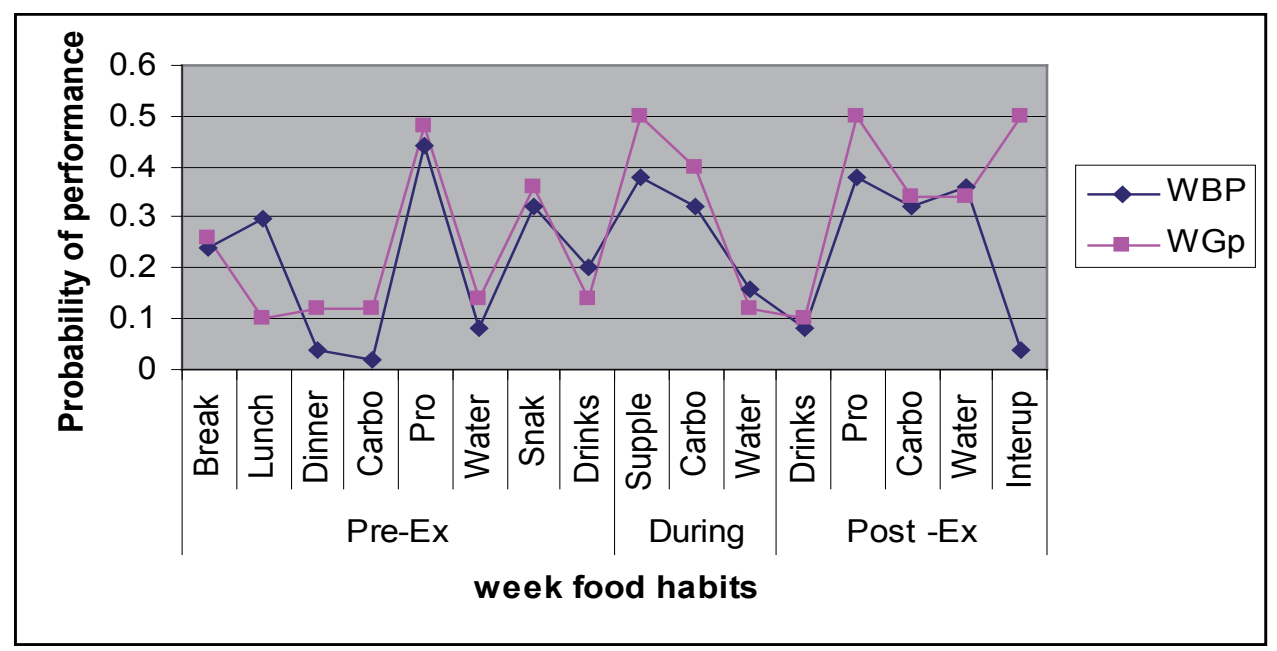

Figure 2. Probability of the Sports Performance of Girls and Boys under Good Food Habit.

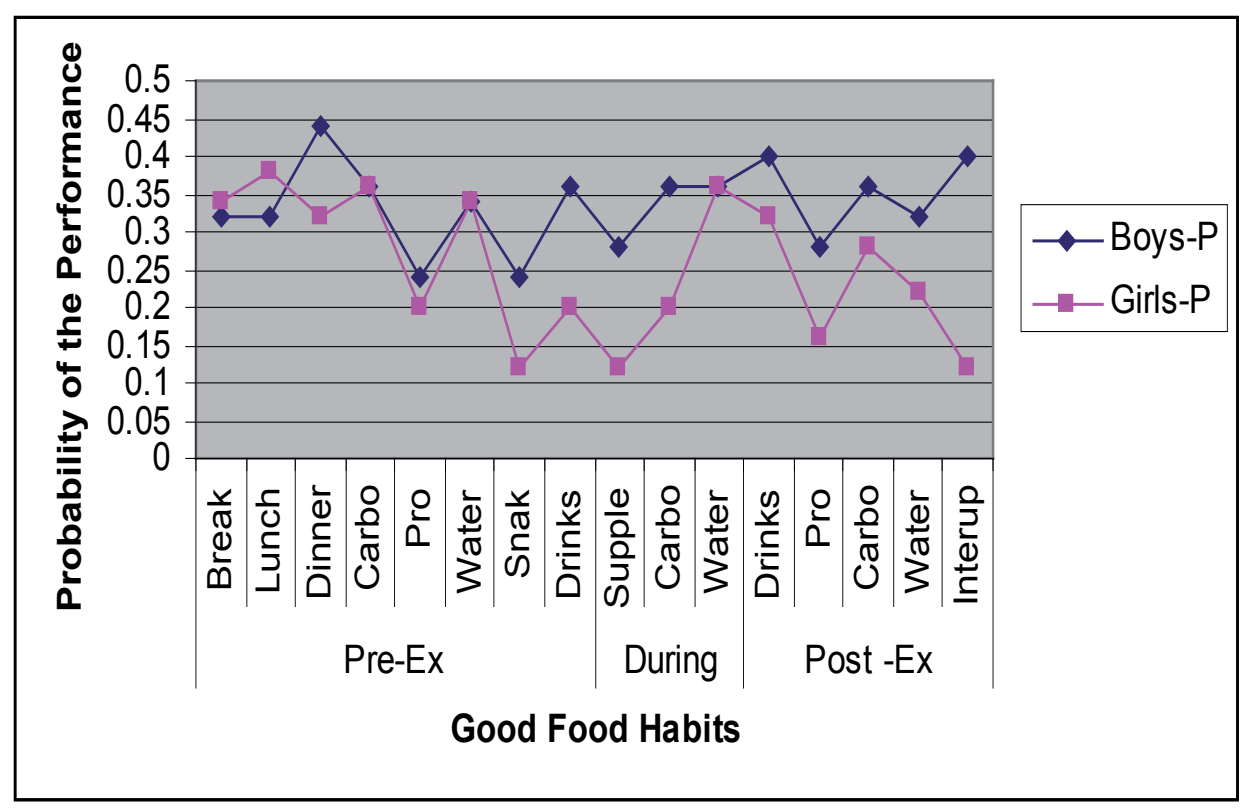


According to the above diagrams probability of the sport performance of girls are significantly higher than boys under week food habits. But regarding with the good food habits the probability of sport performance boys slightly greater than girls.

Table 3. Pearson's Chi-square Test Results of the Gender Difference of Performance Levels.

\begin{tabular}{llllllll}
\hline \multicolumn{7}{c}{ Performance level } \\
\hline \multirow{6}{*}{ Boys } & School & District & Provincial & National & International level & Total \\
& & level & level & level & level & & \\
& Indoor & 0.181 & 0.267 & 0.29 & 3.0 & 0.005 & \\
& Outdoor & 0.356 & 0.40 & 0.019 & 000 & 0.114 & \\
& Indoor & 0.91 & 0.121 & 0.005 & 1.157 & 0.001 & \\
& Outdoor & 0.525 & 0.154 & 0.063 & 0.655 & 0.137 & 7.279 \\
\hline Total & & & & & & \\
\hline
\end{tabular}

$\mathrm{DF}=12 \quad \mathrm{P}$ value $=0.839 \quad 12$ cells with expected counts less than 5.0. According to the above chi square test no significant difference between gender, indoor and outdoor games with the performance.

\section{Conclusion}

The result indicated mix results (both significant differences and no significant difference) in food habits and sport performance among girls and boys. The study revealed that there was significant difference in food habits at the Pre exercises period during the exercise period and post exercise period between girls and boys in some food habits components. Gender difference in sport performance significantly high among girls than boys.

A key priority for sportsman is to establish a wellchosen training diet that can be easily manipulated when special situation emerge. A good base diet will provide adequate morticians and energy to enhance adaptations from training.

\section{References}

Cavadinic, H., Decarli, B., Dirran, H., Candery, M., Narring, F., \& Michaud, P. (1997). Assessment of adolescent food habits in Switzerland. Appetite 32, 97-100.

Narring, F., \& Michaud, P.A. (1995). Methodological issues in adolescent health surveys: the case of the swiss multi centre adolescent survey on health, Soz Praventivmed 40, 172-182.

Australian Sports Institute. Sports Nutrition. web site www.ais.org.au/nutrition

\section{Correspondence}

\author{
Walter SENEVIRATHNE \\ Lecturer/Course coordinator, \\ Postgraduate Diploma in Physical Education \\ Department of Education \\ Faculty of Arts \\ University of Peradeniya \\ Email: walters@pdn.ac.lk
}

